\title{
trabalhonecessário
}

issn: $1808-799 \mathrm{X}$

ano 6 - número 6 - 2008

\section{A atualidade do pensamento de Marx ${ }^{\star}$}

Ana Aparecida Arguelho de Souza* ana.arguelho@terra.com.br

O desenvolvimento político, jurídico, filosófico, literário, artístico, etc., assenta-se sobre o desenvolvimento econômico, mas reagindo uns sobre os outros e sobre a própria base econômica. Isto não se passa devido à situação econômica ser a causa, a única causa ativa e todo o resto exercer apenas uma ação passiva. Pelo contrário, trata-se de uma ação recíproca com base na necessidade econômica, que em última instância, vence sempre.

Karl Marx

\section{Introdução}

Este ensaio trata de levantar algumas categorias e organizar uma reflexão acerca da atualidade do pensamento de Marx para uma leitura da sociedade e da educação contemporâneas. Por que o pensamento de Marx é atual? Podemos até não ter consciência disso, mas expressivas idéias desenvolvidas pelos educadores do mundo todo, contemporaneamente, são desdobramentos, às vezes problemáticos e vulgarizados, ou necessários e radicais, das idéias de Marx e revelam o quanto o seu pensamento infiltrou-se e 
direcionou a educação no mundo. Sempre penso: por que as idéias de Marx atravessaram o tempo e as fronteiras e continuam tão fortalecidas mesmo depois do fracasso do socialismo soviético? A resposta que encontro é sempre a mesma. Atravessa todas as páginas de sua vasta obra um profundo sentimento de humanismo, um comovente amor pelo homem e um desejo cerebral de transformar a vida em alguma coisa digna de ser vivida.

É evidente que, pela amplitude e complexidade da teoria, é necessário centrar a análise em algumas categorias que caracterizam 0 mundo contemporaneamente - mercado, globalização, monopólio, decadência e barbárie. Por meio dessas categorias, pretende-se configurar a sociedade de hoje e, dentro dela, a educação, de modo a demonstrar a atualidade do pensamento de Marx e a necessidade de se estudar a sua teoria para se pensar a sociedade e a educação nos tempos atuais. Para fins didáticos, optou-se por abordar, primeiramente, a sociedade e, por fim, a educação. É importante, ainda, assinalar que, embora revista essa teoria e escoimada de categorias superadas historicamente, optou por nomear de marxismo não só a produção das diversas teorias surgidas a partir da teoria-matriz como também, o conjunto da produção do próprio Marx.

Inicia-se, então, pela descrição do objeto de que trata a teoria, bem como das fontes clássicas que a originaram. A sociedade moderna, ou capitalismo, que inicia por volta dos séculos XV - XVI é o objeto da teoria de Marx. Então, o que estaria fazendo esse pensador em um ensaio sobre educação? Ocorre que, para a teoria de Marx, a educação é um dos componentes que formam a superestrutura da sociedade. Por isso, não é possível compreendê-la, de fato, senão a partir desse seu enraizamento na sociedade e, para tanto, é preciso estudar os mecanismos que a regem.

\section{As fontes}

Uma retomada das fontes clássicas que permitiram a leitura do capitalismo por Marx se faz necessária apenas como revisão metodológica. Em relação a essas fontes, é importante frisar que a teoria de Marx não nasceu de 
meras especulações acerca da sociedade. Nasceu, antes, de um amadurecimento das teorias com as quais se pensou o capitalismo, desde os seus primórdios até o século XIX, quando todas as condições materiais, econômicas e filosóficas da sociedade já estavam dadas, de modo a serem apropriadas, analisadas e superadas, em pensamento, por Marx.

Assim é que o marxismo apresenta uma reflexão profunda e de conjunto acerca da economia política, a partir da crítica que faz a Adam Smith e David Ricardo a respeito da teoria do valor-trabalho, demonstrando que a força de trabalho humana, sob o capitalismo, torna-se mercadoria. O operário vende sua força de trabalho ao proprietário dos instrumentos de produção, empregando uma parte do seu dia de trabalho a cobrir os gastos do seu sustento, que é o seu salário, e a outra parte a trabalhar gratuitamente, criando a mais-valia, fonte do lucro e da riqueza capitalista. Esse é um dos aspectos importantes da teoria marxista, poder-se-ia dizer, o mais importante, que constitui matéria de sua vasta obra O capital (Marx, 1982), porque julga seu autor que não é possível entender uma sociedade sem estudar detalhadamente seus mecanismos econômicos, sendo o capitalismo, antes de mais nada, uma relação social fundada na contradição entre trabalho assalariado e capital.

Outra importante fonte da teoria marxista é a filosofia de Hegel, a qual representa a culminância das grandes filosofias burguesas que, desde os albores do capitalismo, vinham tentando justificar esse modo de produção da vida como aquele que, por fim, seria o mais viável e adequado para a vida em sociedade. Entende Marx que os limites da teoria de Hegel encontram-se na crença daquele filósofo de que a história do homem é a história do pensamento do homem. $\mathrm{Na}$ obra $A$ ideologia alemã (Marx, 1987), escrita a quatro mãos com Engels, ambos demonstram que, em Hegel, a vida resulta do automovimento do pensamento, quando na verdade é o pensamento que é movido, dialeticamente, pelas determinações de última instância, isto é, econômicas, que constituem a base material de uma sociedade. Marx considera que o homem, ao nascer, já traz como herança um conjunto de relações determinadas, com as quais ele tem que se 
haver no processo de produzir a sua própria existência. Em última instância, isso é o que determina sua existência.

Finalmente, o aspecto político da teoria de Marx diz respeito aos enfrentamentos que ele fez ao chamado socialismo utópico. Este é uma forma embrionária de socialismo que critica a sociedade capitalista, sonhando com sua abolição, mas sem explicar a natureza do trabalho assalariado, nem descobrir as leis do seu desenvolvimento, nem encontrar a força social capaz de se tornar o móvel da transformação do capitalismo, a luta de classes. A propósito dos socialistas utópicos, diz Marx que "[...] a forma pouco desenvolvida da luta de classes e a sua própria posição acabam por levá-los a se considerarem muito acima de todo e qualquer antagonismo de classe" (Marx, 1990, p.26). Entende o marxismo que a superação de uma dada forma social é feita por meio do confronto de forças antagônicas. O capitalismo forjou-se no enfrentamento com a sociedade feudal, por exemplo.

A reconstituição da luta pela instauração e o desenvolvimento do capitalismo na história exige um debruçar sobre os teóricos clássicos do liberalismo. É essa luta que tem de ser apreendida quando se lê uma obra clássica. Esse é, inclusive, um ensinamento de Marx, extremamente importante para os educadores da atualidade. Não se pode entender a sociedade de hoje, se não a tomarmos no seu leito histórico, recuperando-a, por meio dos pensadores clássicos que fizeram a história do capitalismo, desde a sua gênese até a sua decadência. A diferença entre essa abordagem e a da historiografia é o componente da luta, que deve ser entrevista na leitura. A título de exemplo, só confrontando Adam Smith e Marx, podemos entender a origem da exploração do trabalho. Só lendo Smith na sua luta contra o monopólio das Corporações de Ofício, podemos entender o que significa o monopólio, na decadência de uma sociedade. E a historiografia, muitas das vezes, omite a contradição e direciona o olhar para o simples encadeamento linear dos fatos, próprio do positivismo, em que não há espaço para a categoria luta. 


\section{Acumulação e decadência}

De modo que o esforço, daqui para diante, será o de recuperar aspectos significativos da luta do capitalismo, no seu processo de decadência, para garantir a produção do lucro e a acumulação do capital, do século $X X$ até nossos dias. E apontar elementos da educação que, por seu turno, possam contribuir para viabilizar o enfrentamento necessário. Essa apreensão só foi possível por meio da leitura de pensadores contemporâneos, no campo da sociedade, como Marshal Berman (1986) Harry Braverman (1987), Robert Kurz (1997), István Mézàros (2002), os quais referendam este ensaio. São autores que formularam suas teorias tomando Marx como fundamento e matriz teórica e que estão buscando atualizar categorias produzidas por Marx, ou formulando novas categorias adequadas ao entendimento do mundo de hoje, sem trair os princípios definidos por ele, ainda que em alguns aspectos suas teorias encontrem divergências. No campo da educação, o professor Gilberto Luiz Alves (2006) referendou a discussão, por travar uma importante discussão acerca da obsolescência da escola contemporânea e da necessidade de sua superação.

Do ponto de vista da teoria marxista, o capitalismo é uma forma social histórica, como todas as que the antecederam e que surgiram no cenário da história, desenvolveram-se e desapareceram para dar lugar a outras formas. Quando uma sociedade não consegue mais responder ao conjunto das necessidades humanas, os homens vão buscar novas formas sociais de viabilizar a vida. Foi assim com o chamado Mundo Antigo; foi assim com a Europa Medieval. É assim também com o capitalismo, cujo próprio surgimento respondeu a necessidades sociais de uma determinada época e tende a desaparecer quando a vida fundada na relação - capital $x$ trabalho assalariado - tornar completamente inviável a vida dos homens.

Até o século XIX, podemos falar de um capitalismo de livre-concorrência entre capitais individuais e nacionais, no seio do qual a burguesia acreditou que, finalmente, a grande indústria seria a solução para a realização plena da vida em sociedade. As sucessivas crises na economia capitalista do final do século XIX, no entanto, começam a apontar a passagem dessa fase concorrencial para a fase 
monopólica que configura a sociedade do século XX até os dias de hoje. MarX assinala esse período como o longo processo de decadência do modo burguês de produzir a vida, isto é, daquele período em que toda uma civilização perde seus parâmetros habituais, construídos ao longo da sua ascensão e apogeu, para ceder espaço a um novo modo de produzir a vida. Considera-se, então, que os séculos XX e XXI representam o desmanche lento e gradativo da forma original da civilização burguesa.

Para Marx, uma civilização entra em processo de decadência pela contradição entre forças produtivas extremamente desenvolvidas e relações sociais já superadas que não suportam mais tal desenvolvimento. A respeito da decadência do capitalismo diz o Manifesto Comunista (Marx, cit., p. 71-2):

As relações burguesas de produção e de troca, as relações burguesas de propriedade, a moderna sociedade burguesa, que fez surgir como que por encanto possantes meios de produção e de troca, assemelha-se ao feiticeiro (Hexenmeister) que já não pode controlar as potências infernais por ele postas em movimento. Há mais de uma década a história da indústria e do comércio não é senão a história da revolta das forças produtivas modernas contra as modernas relações de produção, contra as relações de propriedade que são a condição de existência da burguesia e de seu domínio. Basta mencionar as crises comerciais que, com seu periódico retorno, põem em questão e ameaçam cada vez mais a existência de toda a sociedade burguesa. Nas crises comerciais é destruída regularmente uma grande parte não só dos produtos fabricados, como também das forças produtivas já criadas. Nessas crises, irrompe uma epidemia social que em épocas precedentes teria parecido um absurdo - a epidemia da superprodução. A sociedade vê-se repentinamente reconduzida a um estado de barbárie momentânea; é como se uma situação de miséria (eine Hungersnot) ou uma guerra geral de extermínio houvessem suprimido todos os meios de subsistência; o comércio e a indústria parecem aniquilados, e por quê? Porque a sociedade possui demasiada civilização, demasiados meios de subsistência, demasiada indústria, demasiado comércio. As forças produtivas disponíveis já não favorecem mais o desenvolvimento da produção burguesa [...] ao contrário, tornam-se poderosas demais para essas relações e passam a ser por ela travadas [...] desarranjam toda a sociedade [...] As relações burguesas se tornaram estreitas demais para conter a riqueza por elas mesmas criada.

A citação é longa por ser extremamente ilustrativa das condições materiais que conduziram o capitalismo à sua fase monopólica, que não é outra 
coisa senão o seu período de dissolução. O Manifesto foi produzido em fins de 1847 e início de 1848, portanto, esse desarranjo da sociedade, de que fala Marx, começa a dar sinais por volta da década de 1830, o que mostra que seu processo é longo e convulsivo.

O acirramento da contradição, que Marx menciona, diz respeito ao excesso de tecnologia produzida pelo capitalismo face às contradições geradas pelo modo como essa tecnologia é apropriada pelo mercado e como seus produtos e resultados são distribuídos para 0 conjunto dos homens. Especialmente, nos séculos $X X$ e XXI, esses produtos não se tornam acessíveis a todos os homens, pelas próprias necessidades do capital e sua conseqüente forma de organização. O capital abandona uma situação de livre circulação da mercadoria, de livre mercado, para entrincheirar-se em pólos de acumulação, isto é, passa a centralizar-se e acumular-se de forma monopólica, em poucas mãos e, nesse processo, acaba por produzir uma grande massa humana despossuída. Diz Braverman (1987, p. 222):

A centralização do capital [...] altera a distribuição dos capitais existentes, reunindo 'capitais já constituídos', por meio da destruição de sua independência individual, expropriação do capitalista pelo capitalista, transformação dos muitos capitais pequenos em uns poucos grandes... O capital aumenta em um lugar para uma enorme massa em uma só mão, porque em outro lugar foi perdido por muitas.

No aspecto material da sociedade, uma das tendências apontadas por Marx, ainda no século XIX, é o engessamento do capital pelos monopólios, como forma de sobrevivência, manifestada mais recentemente pelo fenômeno da globalização, eufemismo utilizado pelo pensamento neoliberal para nominar os monopólios. Robert Kurz aponta os principais elementos de ordem material que, no processo de globalização da economia, confirmam a decadência do capitalismo. O primeiro elemento a se colocar em pauta é a banalização do homem transformado em mercadoria, em um mundo em que "Tudo passou a ser negociado a qualquer momento e em toda parte: dívidas do Terceiro Mundo (brady bonds), auto-peças, mão-de-obra barata, órgãos humanos" (Kurz, 1997, p.136). Diz o autor que o mundo passa a ser administrado por jogadores globais 
que buscam produzir onde os salários são baixos, pesquisar onde as leis são mais generosas e auferir lucros onde os impostos são menores; e que o capital cada vez mais demonstra desinteresse por investimentos nas regiões assoladas pela pobreza, cuja população não pode mais ser convertida em mercadoria. "As 'zonas de rentabilidade', porém, que se alteram quase que diariamente, estão distribuídas como um eczema ao longo do globo" (Kurz, cit., p. 139), coexistindo e alternandose com as zonas de pobreza, num tipo de economia difusa.

Com a extinção das economias nacionais, diz Kurz, o espaço histórico das nações passa a ser uma realidade que pertence ao passado. E que, não obstante a economia privada na sua forma global avançar todos os limites, o Estado permanece restrito às fronteiras territoriais, sem voz de comando ativa sobre o mercado global.

Mézàros refina esse pensamento, ao apontar a contradição inelutável entre o aspecto totalizador do Estado do capital e o fato de sua existência só se realizar na forma de Estados nacionais particulares que não conseguem superar sua individualidade. Essa individualidade é vista, então, pelo autor, como uma determinação negativa impossível de ser transformada em positividade. Essa é uma das tantas contradições que levam o autor a sustentar a tese de que o capital atingiu os limites absolutos da controlabilidade de reprodução do seu sistema sociometabólico e que o fazem seguir em frente às cegas,

[...] - sob a lei das sempre maiores concentração e centralização - e em direção à dominação interna e internacional da 'meia dúzia de jogadores globais', repelindo quaisquer preocupações com os riscos explosivos de tais circunstâncias. (Mészàros, 2002, p. 245)

A impossibilidade de reprodução da ordem do capital, confirma Kurz, fará com que, em um futuro próximo, em cada continente, em cada país, em cada cidade, exista uma quantidade proporcional de pobreza e favelas contrastando com pequenas e obscenas ilhas de riqueza e produtividade. Esse prognóstico desenha-se de forma preocupante em diversas cidades brasileiras, num fenômeno típico da decadência, em que uma sociedade não atende mais às necessidades humanas. E é certo que uma economia global limitada a uma minoria sempre mais restrita é incapaz de sobreviver. Se a concorrência globalizada diminui cada vez 
mais o rendimento da produção industrial e assola numa proporção ascendente a economia das regiões, afirma o autor, segue-se logicamente que o capital mundial minimiza seu próprio raio de ação. "A longo prazo, o capital não poderá insistir na acumulação sobre uma base tão restrita, dispersa por todo o mundo, do mesmo modo como não é possível dançar sobre uma tampinha de cerveja" (Kurz, cit., p. 140).

Essa linha de pensamento, que já estava em Marx, a da expulsão dos trabalhadores e da produção de um exército de reserva a partir dos operários excedentes da produção industrial, retoma o mesmo autor, afirmando:

[...] são sobretudo as reações desesperadas dos homens cuspidos do mercado que desencadeiam a crise do novo sistema mundial. Os custos da segurança crescem em proporções astronômicas. Os antigos países imperialistas [...] são obrigados a mobilizar conjuntamente uma "polícia mundial" contra os perdedores globais, a fim de garantir condições sociais condizentes às ilhas de riqueza. (Kurz, cit., p. 140)

A atualização da teoria de Marx por Kurz permite-Ihe reconceitualizar o exército industrial de reserva, expressão que cabia ao tempo de Marx, quando o desemprego estrutural que assola o mundo globalizado ainda não era uma realidade, podendo, portanto, a mão-de-obra expurgada dos setores produtivos ser aproveitada em outros ramos da produção, de acordo com as necessidades do mercado. Na atualidade, essa mão-de-obra não tem sequer a chance do retorno ao emprego e uma vez expulsa do mercado passa a compor o exército dos perdedores globais.

Diferentemente do que apregoam as forças conservadoras da sociedade, por meio do discurso neoliberal, a teoria de Marx permite compreender que o fenômeno da globalização não representa mais um dos sete fôlegos do capitalismo como modo de produzir a vida eternamente; revela, sim, o acirramento de contradições, expressando muito mais as impossibilidades de o capital se realizar sob as relações sociais vigentes, do que suas possibilidades de produzir a vida, na atualidade. Sua impossibilidade está expressa no esgotamento dos empregos e dos mercados pela não realização da mercadoria.

Pela primeira vez na história da modernidade, uma nova tecnologia é capaz de economizar mais trabalho, em termos 
absolutos, do que o necessário para a expansão dos mercados de novos produtos. Na terceira revolução industrial, a capacidade de racionalização é maior do que a capacidade de expansão. A eficácia de uma fase expansiva, criadora de empregos, deixou de existir. O desemprego tecnológico da antiga história da industrialização faz seu retorno triunfal, só que agora não se limita a um ramo da produção, mas se espalha por todas as indústrias, por todo o planeta. (Kurz, cit., p. 164-165)

O desemprego e a existência material de perdedores globais, de que fala Kurz, estão diretamente ligados ao princípio do lucro, pela extração de mais-valia, uma vez que o lucro e a acumulação constituem princípio e fim do capital e só se realizam por meio da mais-valia, do trabalho excedente do operário.

Marx demonstra que, nos primórdios da indústria moderna, a forma de exploração do trabalho humano se fazia por meio da mais-valia absoluta, isto é, o estágio tecnológico alcançado, então, pelo capital, exigia que grandes contingentes de trabalhadores cumprissem, no interior das fábricas, uma extensa jornada de trabalho. Na sua fase monopólica, a necessidade de fazer frente à concorrência do mercado internacional tem exigido dos setores produtivos a incorporação de ciência e tecnologias cada vez mais sofisticadas na produção das mercadorias e cada vez mais rapidez na substituição do aparato produtivo. Além do que, gastos dispendiosos com marketing e publicidade tornam-se indispensáveis para garantir um lugar no circuito do mercado mundial.

Essa situação tem levado os setores produtivos a adotarem medidas de contenção de custos, nas quais se inclui a dispensa maciça de trabalhadores da produção, com o propósito de aumentar a capacidade produtiva, isto é, mais qualidade a menor custo. Como, porém, a diminuição de custos não pode significar a redução de mais-valia e, portanto, do trabalho assalariado, a solução encontrada pelo capital tem sido reorganizar o sistema de trabalho de modo que menos trabalhadores produzam mais mercadorias.

É Ricardo Antunes (1995) quem discorre sobre as metamorfoses no mundo do trabalho, decorrentes dessa necessidade do capital, que vem informando a tão alardeada substituição dos modelos taylorista e fordista de produção pelo toyotismo, ou modelo de acumulação flexível. A característica básica deste último reside na polivalência, isto é, na capacidade de um mesmo 
trabalhador operar, simultaneamente, várias máquinas. As diversas operações do processo de trabalho, sendo desenvolvidas por um só trabalhador, permitem, por um lado, a dispensa de grande número de trabalhadores da produção e, por outro, o aumento de trabalho excedente para os que ficam. A intensificação da exploração do trabalho é o que Marx chamou de mais-valia relativa, neste fim de milênio, levada aos extremos.

Esse movimento do capital tem uma finalidade muito precisa: evitar a queda na taxa média global do lucro e garantir o curso da acumulação. Com isso, a grande questão que se coloca como impositiva para o desmanche do capitalismo, de suas relações sociais, suas instituições, seu modo de "tocar a vida", é que a dispensa de trabalhadores em proporções tão gigantescas passa a ameaçar a ordem social em seus fundamentos. Nesse sentido, o capital não tem saída: para competir no mercado mundial precisa dispensar trabalhadores e essa dispensa significa perda de poder aquisitivo dos excluídos do mercado e, portanto, a desrealização da mercadoria, gerando um pólo de miséria tão gigantesco que inviabiliza a própria realização da vida, no patamar das relações sociais capitalistas. A argumentação de que um novo modo de trabalhar está surgindo, a falácia da empregabilidade, tudo desmorona diante do volume de desempregados que não conseguem retornar ao mercado. Viviane Forrestier, em sua obra $O$ horror econômico (1997), já na década de 90, traçou um panorama sombrio e dramático a respeito da impossibilidade de o capitalismo, na sua forma contemporânea, gerar empregos em níveis compatíveis com as necessidades materiais dos homens. Essa situação altera toda a organização da sociedade, toda sua estrutura, as bases em que se assentam as relações, a vida enfim. A crise do desemprego é mundial e está além das possibilidades de os governos criarem empregos.

De modo que a decadência, como já demonstrara Marx, diz respeito a esse desarranjo estrutural da sociedade, pela dissolução que sofre a forma capitalista de trabalho, todas as suas instituições, seus valores, seus instrumentos conceituais, seus paradigmas, no processo histórico de acirramento das contradições entre capital e trabalho assalariado. Ou seja, a causa primeira de 
todo esse desmanche que vem sofrendo a sociedade está na forma como o capital realiza a acumulação.

É também a teoria de Marx que vai nos permitir apreender que esse processo de desconstrução da sociedade produz, em seu interior, uma nova forma social qualitativamente diferente da forma do capitalismo. Na dialética da sociedade em movimento, forças antagônicas se interpenetram, exercem e sofrem influências mutuamente, produzindo o caos e a incerteza, mas também instigando à luta, provocando desafios e assim compondo o cenário histórico propício a uma nova civilização. Marshall Berman, na obra Tudo que é sólido desmancha no ar, afirma: "A desintegração trabalha como força mobilizadora e, portanto, integradora [...] Dizer que nossa sociedade está caindo aos pedaços é apenas dizer que ela está viva e em forma” (1986, p.95). A decadência significa, assim, na perspectiva do marxismo, apenas o esgotamento das possibilidades materiais de uma sociedade de, no conjunto de determinadas relações, dar prosseguimento ao existir dos homens dentro dos patamares civilizatórios até então alcançados.

Quando uma sociedade entra em decadência, novas forças sociais emergem em seu interior e entram em confronto com as forças conservadoras, até que uma nova sociedade se instaure. Isso é o que faz dos homens sujeitos da história. É importante registrar o processo de luta, porque, sem a luta dos homens para a instauração de uma nova sociedade, uma forma social em decadência pode, facilmente, entrar em um processo de barbárie, sem novas possibilidades civilizatórias.

É preciso diferenciar decadência daquele estado de barbárie mencionado por Marx. Trata a barbárie, nesse desmanche da sociedade, das realizações materiais e espirituais dos homens, que não conseguem incorporar os germes da nova civilização, isto é, que reproduzem antigas formas, inertes e cristalizadas. A barbárie é produzida no interior de uma sociedade em decadência como expressão da imobilidade, do marasmo e da sensaboria. Esses elementos marcam a vida, as instituições e as produções conservadoras, isto é, aquelas que reproduzem de forma grosseira, na linguagem ou no conteúdo, as coisas passadiças e, assim, vão alimentando a sociedade em coma. Em tempos de 
decadência, os sinais da barbárie são visíveis e manifestam-se na quase totalidade dos comportamentos, das linguagens e das produções humanas. E são sedutores, na medida em que a grande maioria das pessoas, também atingidas pela decadência, se reconhece nesses produtos barbarizados e incorpora sua materialidade. Para Kurz, em tempos assim, o debate teórico cede lugar a uma espécie degradada de literatura especializada, em vez de crítica, auto-ajuda. No melhor dos casos,

Entra em cena em lugar de uma reflexão acerca da totalidade social [...] o recitar monótono de um sequioso pensamento [...]. A máquina de conceitos do pensamento ocidental perdeu sua força material e parece se despedaçar antes do sucateamento [...]. Essas teorias-antiteóricas parecem apenas retomar e dar continuidade ao traço afirmativo do estruturalismo e da teoria sistêmica [...] e o mundo científico parece não ser mais capaz de recobrar a força necessária para oferecer respostas às situações que as exigem. (Kurz, cit., p.18-19)

Não é difícil perceber que às teorias formuladas no século $X X$, de um modo geral, falta esse largo fôlego da teoria de Marx, para resolver os problemas colocados pela sociedade, inclusive, no interior da educação formal. São teorias que tratam das singularidades das questões humanas, mas não tocam o universal. E não tocam exatamente porque a ciência especializada não trabalha com o universal. Cada singularidade abordada, entretanto, não é só o que aparenta ser. Cada singularidade traz em si os germes do universal, encerra em si as contradições da sociedade, como se discutirá a seguir.

\section{Educação e decadência}

Para centrar a discussão no âmbito da educação, tome-se a questão do livro didático, como um dos instrumentos da escola, que por sua predileção entre professores e incentivo do MEC, merece uma reflexão. A primeira questão sobre o livro didático é que ele não é apenas um instrumento de ensino, é mercadoria, traz embutido em si uma relação social, a exploração do trabalho. Sua fabricação e circulação são importantes para o processo de acumulação do capital. Por isso, não importa muito para o fabricante a qualidade do seu conteúdo. Importa o que 
ele vai vender, o que vai render de lucros e em que medida vai possibilitar a reprodução do capital.

Essa pode ser a razão porque um livro didático da área de linguagens, distribuído pelo Ministério da Educação para as escolas da rede pública de Ensino Médio, do ponto de vista do seu conteúdo, é extremamente revelador da barbárie a que se aludiu anteriormente. Fragmentos de texto, geralmente selecionados por critérios dúbios; exercícios de interpretação que tocam apenas a superficialidade das questões propostas no texto; exercícios gramaticais descolados do texto; a grande literatura substituída por resumos, por biografias de autores e por características de escolas literárias, para efeito de atender exigências dos vestibulares. Nada que apaixone o aluno, nada que dê sentido à sua existência no mundo, que lhe permita se reconhecer como humano, como construtor da história. O aluno, desmotivado pela fragilidade do material didático, estuda por estudar, como uma obrigação, pois perde a emulação que o reconhecimento de si, no objeto estudado, provoca. O conhecimento, visto assim, de modo abstrato e fragmentado, descola-se das suas condições de produção, isto é, do contexto, da materialidade e das intencionalidades que demandaram a sua produção.

Essa situação não acontece por acaso. Alves (2006, p. 174 - 2008) demonstra que a instituição escolar pública, nesta fase monopólica do capitalismo, entre as diversas funções que exerce, toma para si a de alocar para o seu interior os trabalhadores expulsos das atividades produtivas e seus filhos. Com isso, 0 Estado procura amainar as tensões provocadas pelo desemprego em massa e contribuir para que o capital mantenha-se no curso da acumulação sem maiores traumas. Essa relação entre a escola e o acúmulo de capitais, feitas as devidas mediações, pode explicar porque as investidas do Estado na educação nem de longe roçam a questão do conhecimento. Ao contrário, o Parecer CNE/CEB 15/98 (Nunes, 2002, p. 77), que trata do Ensino Médio, versa sobre a necessidade de se desbastar o "currículo enciclopédico" congestionado de informações desarticuladas. Todavia, não é desbastando o currículo escolar que se resolverá a questão, pois desbastados eles já estão no livro didático. Ao contrário, é preciso que o texto ganhe fôlego na sala de aula, para que os conhecimentos ali hauridos 
sejam re-significados à luz da sua historicidade. Para isso, a sugestão é que a escola substitua o principal instrumento de vulgarização do conhecimento, o livro didático, pela literatura da obra clássica e contemporânea e por outras diversas linguagens estéticas e conceituais, por meio das quais os alunos poderão construir uma nova visão de mundo e re-significar valores e condutas morais. Mas isso só será possível se a leitura das diversas linguagens presentes nos textos for realizada com base em um método que permita a reconstituição histórica dos conhecimentos trazidos por essas linguagens. E não com base na historiografia de cunho positivista, mas de uma história vista a partir das lutas dos homens como motor da construção civilizatória. Aí sim, as demais competências, éticas, econômicas, estéticas, reivindicadas pela mesma Resolução, ganharão significado, pois estarão a serviço da construção de uma sociedade mais justa e igualitária, para cuja realização, certamente, os alunos egressos do Ensino Médio estarão melhor aparelhados.

A adoção de textos clássicos na sala de aula é parte de um conjunto de princípios e medidas pedagógicas desenvolvidas por ocasião da elaboração do Referencial Curricular para o Ensino Médio de Mato Grosso do Sul, cuja escrita coordenamos durante o governo do PT, no Estado. Também esse conjunto está presente em um curso de Pedagogia, instaurado na UEMS, pólo de Campo Grande, cuja escrita teve a nossa intensa participação. Essas idéias encontram sustentação nas teorias desenvolvidas por Alves.

Atenta esse pesquisador para o fato de que a organização do trabalho didático, no interior da escola da atualidade, é obsoleta e ultrapassada, porque as tecnologias com que opera são próprias do período manufatureiro. O manual didático é um exemplo disso. Formulado por Comenius, no século XVII, para auxiliar o professor na tarefa de ensinar um grande número de crianças, esse instrumento "pela sua auto-suficiência enquanto instrumento organizador do trabalho de ensino, dispensou da escola o livro clássico" (Alves, cit., p. 77). A utilização massiva do manual didático, contemporaneamente, é uma confirmação de que a escola, ainda hoje, prescinde do conhecimento. Naturalmente, a adoção de manuais didáticos na escola traz conseqüências, do ponto de vista civilizatório, 
porque a vulgarização e a superficialidade das informações neles contida não permitem a apreensão da totalidade histórica.

Tão problemáticas quanto o manual didático são as metodologias de apreensão do conhecimento, propostas pelos órgãos federais de gestão da educação, nessa mesma perspectiva da totalidade. A partir das conseqüências advindas de um ensino pautado em manuais, que prima pela fragmentação e pelo recorte, documentos oficiais, como o Parecer 15/98, já referido, e os PCNs por exemplo, propõem, para o Ensino Médio, a interdisciplinaridade como recurso para recuperar a totalidade do conhecimento fragmentado pelo manual didático, 0 que, julga-se, é o esforço equivocado de somar informações que não dão conta de explicar porque, apesar do atual desenvolvimento das forças produtivas, a humanidade ainda não alcançou a satisfação plena das suas necessidades. Porque esse é, verdadeiramente, o problema a ser compreendido pela educação que visa formar cidadãos: a sociedade não consegue sustentar a vida, as necessidades de um quantitativo imenso de pessoas, enquanto outras vivem, como disse o Kurz, em ilhas de riqueza. Portanto, se o que se almeja é uma educação que permita compreender a luta e a contradição, não se pode creditar beneficio à interdisciplinaridade.

Essa é uma categoria com a qual não se pensa muito longe. Com ela se pensa a sala de aula e, no máximo, o bairro do aluno. Mas, o bairro é apenas a singularidade de um mundo que oprime. O olhar para o bairro, a cidade, as condições do transporte, da moradia, remetem a efeitos e não a determinações históricas mais abrangentes. A universalidade é dada pela teia de relações sociais, no caso, as relações capitalistas de produção. Qualquer singularidade a ser estudada, quer seja a depredação do meio ambiente, quer seja uma obra literária, requer a compreensão de que essa singularidade traz em si as contradições do seu tempo histórico, isto é, da totalidade do capitalismo. E isso, a interdisciplinaridade não revela.

Esse conceito, não por acaso, ganha expressão e notoriedade no momento em que as empresas buscam, por meio do trabalho polivalente, uma forma de resolver a organização produtiva por meio da intensificação da exploração do 
trabalhador. E mais, no momento em que o discurso neoliberal tenta responder à crítica de que o trabalho produtivo parcializado inviabiliza ao trabalhador uma percepção de totalidade. Tomada ao mundo do trabalho, re-significada pelo discurso educacional e trazida para o interior da escola, a interdisciplinaridade obedece ao mesmo princípio da polivalência. Esta é defendida pelo setor produtivo como a educação que permitiria ao operário uma visão de totalidade, por meio da articulação de várias competências técnicas no interior da fábrica. Aquela supõe a compreensão da totalidade, pela articulação de informações de diferentes áreas do saber, ao aluno. Resta perguntar de que totalidade se está falando em um e outro caso. Se é a do bairro para o aluno e da fábrica para o operário, ou se a totalidade do capitalismo que oprime um e veda os olhos do outro.

Ora, a solução para o trabalhador não está na reorganização produtiva que Ihe permite compreender várias etapas do trabalho produtivo, nem para o aluno está na reorganização interdisciplinar dos conteúdos por meio de uma somatória inócua de informações. Tanto para o operário como para o aluno, a solução está em compreender seu papel, suas possibilidades e limites de cidadão, no interior do movimento e da lógica da acumulação de capitais, naquilo que esse movimento e essa lógica tornam excludente e injusto o processo de construção da cidadania.

Nesse sentido é que se reivindica a adoção de clássicos na sala de aula do Ensino Médio. Não se pretende, com isso, uma volta à Idade Média, quando o ensino preceptorial era ministrado por meio dos clássicos, mas, de algum modo compreender que:

O confronto entre discursos de diferentes épocas permite perceber, na lógica interna que os costura, o movimento social dessas épocas. São discursos ideológicos, porque estão assentados em princípios e finalidades postos por necessidades e exigências de cada época. Assim, quando uma sociedade está em formação leiam-se os textos que ela produziu e ver-se-á neles os pilares dessa construção e a luta dos homens para combater a sociedade anterior; quando ela atinge seu apogeu, as linguagens são expressas em discursos que revelam na sua organização a majestade do período. E quando a mesma entra em estado de desintegração, consultem-se os discursos e encontrar-se-á na sua forma organizativa, o movimento de desintegração/ integração, 
sua convulsão e a germinação de novos elementos sociais. (Souza, 2004, p. 18)

Confirma essa assertiva a análise comparativa entre obras literárias produzidas nos séculos XIX e XX. Nas primeiras, a organização linear de uma prosa de acontecimentos sucessivos; nas segundas, a fragmentação narrativa, temporal, a desrealização da personagem e outros componentes estéticos que apontam nitidamente para uma sociedade em fragmentos. Nesse sentido, a leitura dos clássicos pelos alunos é necessária, na medida em que o exame dos diversos discursos aponta os sinais das transformações sociais. Já a recorrência à teoria marxista, enriquecendo a análise estética, é fundamental à recuperação das categorias da luta e da contradição, nas obras estudadas. São estas categorias que permitem compreender o capitalismo em seus fundamentos, o dês-valor do homem, transformado em mercadoria em razão do lucro e a desumanização própria dos tempos de barbárie. A recorrência a essa teoria, como princípio e método de apreensão do conhecimento extraído das leituras permite reconstruí-lo na perspectiva da luta pela humanização do homem, travada ao longo da história. A historiografia e os manuais didáticos podem até nos revelar que o homem saiu das cavernas e chegou até aqui. A teoria de Marx nos revela com que instrumentos e recursos os homens puderam sair das cavernas e construir civilizações, toda sua luta, suas intenções, suas utopias e paixões, nessa formidável empreitada. De forma que se considera o marxismo extremamente fecundo e necessário para o entendimento radical das questões humanas, incluindo aí a educação formal, ainda que os parâmetros nacionais apontem outros caminhos.

\section{Considerações}

Espera-se ter demonstrado a relevância de se recorrer a Marx para o entendimento do homem, que é o princípio e o fim da educação, para o entendimento do capitalismo, no que ele coisifica e reduz o homem e para a necessidade de buscar sua superação. E que as obras clássicas sejam trazidas 
de volta aos bancos escolares, como instrumentos de apreensão das contradições e da luta.

Embora os sinais da decadência desta sociedade possam ser vislumbrados em todas as instituições e valores, inclusive na instituição escolar, a relação capital-trabalho assalariado ainda dá sustentação ao capitalismo e, enquanto for assim, a teoria de Marx será de utilidade para explicar o mundo e a educação. Ela só perderá sua validade, e a perderá, por sua natureza histórica, quando o capitalismo for superado.

* O texto original, que deu origem a este ensaio, foi a palestra de abertura do III Seminário em Educação - Revisitando os pensadores. Paranaíba/UEMS - 2006 e passou por várias revisões até adquirir a formatação aqui exposta.

** Professora e pesquisadora da Universidade Estadual de Mato Grosso do Sul. Doutora em Letras pela UNESP - campus Assis e Mestre em Educação pela UFMS. Para consulta da produção, vide Lattes.

\section{Referências}

ALVES, Gilberto Luiz. A produção da escola pública contemporânea. 4.ed. Campinas, SP: Autores Associados, 2006.

ANTUNES, Ricardo. Adeus ao trabalho?: ensaios sobre as metamorfoses e a centralidade do mundo do trabalho. 6.ed. São Paulo: Cortez; Campinas. SP: Editora da Universidade Estadual de Campinas, 1995.

BERMAN, Marshall. Tudo que é sólido desmancha no ar: a aventura da modernidade. Tradução: Carlos Felipe Moisés e Ana Maria L. Ioriatti. São Paulo: Companhia das Letras, 1986. 
BRAVERMAN, Harry. Trabalho e capital monopolista: a degradação do trabalho no século XX. Tradução: Nathanael C. Caixeiro. 3.ed. Rio de Janeiro: Editora Guanabara S/A.,1987.

FIGUEIRA, Pedro Alcântara (tradutor e organizador). Economistas políticos. São Paulo: Musa Editora; Curitiba: Editora Segeste. 2001.

FORRESTIER, Viviane. O horror econômico. Tradução: Álvaro Lorencini. São Paulo: Editora UNESP, 1997.

KURZ, Robert. Os últimos combates. 3.ed. Petrópolis: Vozes, 1997.

MARX, Karl. O capital: crítica da economia política. Trad. Reginaldo S'Antanna. 7.ed. São Paulo, Difez, 1982.

MARX, K.; ENGELS, F. A ideologia alemã. Tradução de José Carlos Bruni e Marco Aurélio Nogueira. 6. ed. São Paulo: Hucitec, 1987.

- Manifesto do partido comunista. Tradução Marco Aurélio Nogueira e Leandro Konder. 3.ed. Petrópolis: Vozes, 1990.

NUNES, Clarice. Diretrizes Curriculares Nacionais: ensino médio. Rio de Janeiro: DP\&A, 2002.

MÉZÀROS, István. Para além do capital. Tradução de Paulo César Castanheira e Sérgio Lessa. São Paulo: Boitempo Editorial; Campinas: Editora da UNICAMP, 2002.

SAVIANI, Dermeval. Escola e democracia. 10. ed. São Paulo: Cortez, 1986.

SOUZA. Ana Aparecida Arguelho de. (organizadora). Referencial curricular para as escolas de Ensino Médio de Mato Grosso do Sul - Área de linguagens, códigos e suas tecnologias. SE/MEC/BID, Campo Grande: 2004. 